\title{
Does Online-Formed Peer Relationship Affect Academic Motivation During Online Learning?
}

\author{
Ignasia Geralda Vania \\ Faculty of Psychology, Universitas Padjadjaran, West Java, Indonesia \\ ignasial800I@mail.unpad.ac.id \\ Whisnu Yudiana \\ Faculty of Psychology, Universitas Padjadjaran, West Java, Indonesia \\ whisnu.yudiana@unpad.ac.id \\ Hery Susanto \\ Faculty of Psychology, Universitas Padjadjaran, West Java, Indonesia \\ hery.susanto@unpad.ac.id
}

\begin{abstract}
The covid-19 pandemic has caused most schools and universities in Indonesia to face a new learning situation called Pembelajaran Jarak Jauh (PJJ) or online learning. Furthermore, this situation also has an impact on first-year students who are about to enter higher education. As the pandemic gets worse, they are not able to get to know their social and academic environment face-to-face. Thus, this study aimed to find the role of online-formed peer relationships on students' academic motivation during the online learning period. Based on a sample of 118 firstyear students from a university, this study found that participants had a high quality of peer relationships and academic motivation. Moreover, peer relationships significantly predict students' academic motivation. However, participants who had interacted entirely online with their friends had a significantly lower quality of peer relationships. This result suggests the importance of building good peer relationships to support students' academic motivation, especially in the pandemic.
\end{abstract}

Keywords: academic motivation, online learning, peer relationships.

Received 15 October 2021/Accepted 23 February 2022 @Author all rights reserved

\section{Introduction}

Since early 2020, Indonesia has been affected by the outbreak of coronavirus disease (Covid-19), which threatens public safety (Samudro \& Madjid, 2020). In response to this situation, various solutions have been made to prevent and control the spread of the virus. One of them was restricting schools and universities from holding offline or face-to-face classes (ZA, Putra, Sofyan, \& 


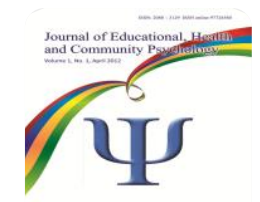

Bimo, 2020). Therefore, the Ministry of Education and Culture Republic of Indonesia made a policy that requires all educational institutions to carry out fully online learning called Pembelajaran Jarak Jauh (PJJ). The online learning process can be varied from lecturing through video conferences, assignments, reading books, journals, etc. This policy continues from March 2020 until August 202I due to the worsening condition of the Covid-19 outbreak in Indonesia.

Another problem that has arisen due to the Covid-19 pandemic is also experienced in the education sector, particularly by the first-year students who have just entered college. When first-year students enter college, they need to adjust themselves to a new environment both academically, socially, and emotionally (Astrini, 20II). This transition period from high school to college is usually supported by the student orientation program held by the university. However, amid the Covid-19 pandemic, this kind of activity cannot be carried out face-to-face. For the first time, student orientation programs must be carried out online by almost all universities in Indonesia. This online or remote method has attracted our attention, considering how students can only get to know the social environment of their college virtually. Undoubtedly, online learning could be an effective method (Bahasoan, Wulan Ayuandiani, Muhammad Mukhram, \& Aswar Rahmat, 2020). By using the various platform of video conferences, students can participate in activities such as student orientation programs, lecturing or seminar anywhere as long as they have their gadgets and internet. In this context, first-year students who are just getting to know the campus environment must start the learning process without any direct (offline) interaction with the teacher or their friends. The online learning method requires independence, self-direction, and intrinsic motivation from the students (Hartnett, 2016). These three aspects depend on the individual's ability to interpret the agency in learning, initiating, and maintaining meaningful communication to engage and understand the material provided (Hartnett, 2016). However, Chiu, Lin, \& Lonka (202I) found that stress and anxiety that may arise in a pandemic situation are said to reduce motivation and make students not involved in learning (Chiu et al., 202I). This situation can be caused by negative emotions (stress and anxiety), which according to Pekrun et al. (20I7), can result in lower academic achievement. Research by Hanesty \& Karneli (202I) found that the decrease of academic motivation during the Covid- 19 pandemic can also be caused by the lack of motivational support, direction, and counseling from parents and teachers. 


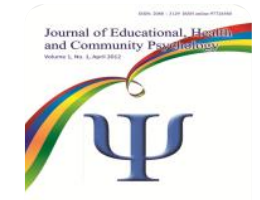

The decrease in motivation during online learning is feared to impact the students' academic achievement. In fact, academic motivation is a psychological dimension that plays a vital role in learning and development, especially in the online learning context (Hartnett, 2016). Academic motivation refers to the drives that underlie individual behavior related to persistence, learning, and academic performance (Wilkesmann \& Virgillito, 2015). According to the theory Deci \& Ryan (1985) related to Self-Determination Theory (SDT), motivation is divided into three types, namely intrinsic motivation (feelings of pleasure and satisfaction obtained from the activity itself), extrinsic motivation (engage in activities for the sake of rewards or to avoid punishment), and amotivation (do not feel motivated because they do not perceive a contingency between actions and the results obtained). When they are motivated and involved in the learning process, they are more likely to internalize the materials better (Hosan \& Hoglund, 2017). Research has also found a positive correlation on how academic motivation affects students' achievement through their grade point average (GPA) (Pekrun et al., 2017; Usher \& Morris, 20I2).

There are various factors that influence academic motivation. First, a teacher can provide support to students' choices and interests. Thus, students will be helped to gain personal interest, involvement, and ownership of their work which can increase student motivation (Schuitema, Peetsma, \& van der Veen, 2016). Then, individual expectations, goals, and values, which are the motivational beliefs, affect students to motivate and direct their behavior in the self-regulatory process, which is the students' ability to control their motivation to learn (Paulino, Sá, \& Silva, 2016). Another prominent factor is peer relationships. Through peer relationships, students can get rewards, reinforcement, or pressure (Elliot, Dweck, \& Yeager, 2017), such as feedback, formation of achievement parameters, and collaboration (Amin, Hassan, \& Jalil, 2018).

Peer relationship is one factor that attracted our attention, considering how first-year students must get to know and interact with their friends online since the beginning of their college life. However, based on the research conducted by Chan \& Cheng (2004), online friendships or known as computer-mediated communication (CMC), are more difficult to develop, especially in terms of commitment, depth of understanding, intimacy, and dependence on one another. Therefore, the quality of this type of friendship is lower than friendships whose interactions are done face-to-face 


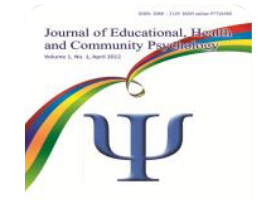

(Baiocco et al., 20II; Chan \& Cheng, 2004; Glüer \& Lohaus, 2016). In fact, peer relationships also contribute to students' learning and educational process (Lee et al., 2020; Rohrbeck \& Garvin, 2003). In this case, peers act as academic enablers who can facilitate student participation in the classroom (Wentzel, 2017). The facilities provided by these peer relationships consist of giving feedback, achievement parameters (Amin et al., 2018), and motivation for the students themselves (Razak \& See, 2010; Shanti, Janssens, \& Setiadi, 202I). In light of the findings from Filade et al. (2019), peers can help students be motivated to obtain the best results. Conversely, peer relationships can also plunge individuals into negative actions. Peer influence is given through rewards, reinforcement, or pressure (Elliot et al., 2017). However, this motivation could only develop if individuals perceive their peers as a positive and supportive group (Wentzel, 2017).

Based on research conducted by Buote et al. (2007), Estiane (20I5), and Shanti, Janssens, \& Setiadi (202I), peer relations are one of the crucial aspects, especially for first-year students. This finding is supported by the correlation found between the quality of peer relationships formed when entering college and their ability to adapt to their new environment (Buote et al., 2007; Furrer \& Skinner, 2003; Rohrbeck \& Garvin, 2003; Shanti et al., 202I). Peer relationship is one mechanism that helps individuals overcome the difficulties and stress associated with the transition from teenager to adulthood (Tokuno, 1986). According to Buote et al. (2007), peer relations play a role in accommodating and helping individuals deal with new environments, providing a sense of belonging, emotional support, feedback, and role models for students themselves. In addition, the research found that individuals also gain feelings of self-worth and self-esteem through their friends (Antonopoulou, Chaidemenou, \& Kouvava, 2019; Willard W Hartup \& Stevens, 1997; Maunder \& Monks, 2019). Therefore, it becomes a concern if the first-year students find it challenging to develop a friendship. It is feared that later they will find it difficult to face the transition from school to college and adapt to the new environment on campus. These difficulties are also feared to be a distraction that makes individuals less motivated in learning.

There are three levels in a peer relationship, namely individual (personal characteristics), dyadic (mutual), and group (Bornstein, Davidson, Keyes, \& Moore, 2003). Peer relationships can be dyadic when viewed from the interactions and relationships that exist in them. Interaction is a pattern that 


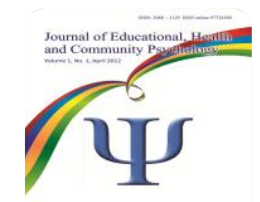

exists in a relationship. In this case, the interaction is characterized by the presence of two parties who respond to each other's actions (mutually). Then, these interactions will affect aspects of cognition, emotion, expectations, and qualifications that form relationships between peers (Bornstein et al., 2003). According to Bukowski, Hoza, \& Boivin( 1994), dyadic peer relationships (friendship) consist of dimensions, namely companionship, help, security, closeness, and conflict. Those are the dimensions that play an important role in determining the quality of peer relationships.

Several factors can affect individuals' peer relationships, such as characteristics, gender, culture, socioeconomic status, relationship with parents, and mode of interaction. However, when referring to the mode of interaction, which is related to the pandemic context, the difference in quality between peer relationships that are accompanied by face-to-face communication and those that are only done online (CMC) is due to the limited interaction in only one communication channel (Chan \& Cheng, 2004). Those who interact with their friends offline can establish communication through various activities that are carried out either face-to-face or online. Unlike CMC, communication is only done through one channel, namely social media. This causes a lack of social context cues in their interactions, such as the interlocutor's spatial features and personal appearance (Chan \& Cheng, 2004). That means that individuals are able to process the information provided based on the strength of their arguments, but not from peripheral cues. This can lead to conflicts caused by miscommunication among individuals (Ishii, 2010). Then, online friendships are not enough to build intimacy (Mesch \& Talmud, 2006; Tang, 2010). In fact, intimacy is important in building relationships in friend relationships (Mesch \& Talmud, 2006; Snow, 2007). Through intimacy, peer relationships can be accompanied by higher self-disclosure, reciprocity, emotion, and interaction.

Given these findings from previous studies presented above, it can be concluded that peer relationships have a positive role in students' academic motivation. However, there are still very limited studies about peer relationships and their role on academic motivation during online learning, especially in a pandemic. Those studies have only been carried out in a context where students can still meet face-to-face (Amin et al., 20I8; Buote et al., 2007; Hosan \& Hoglund, 2017; Razak \& See, 2010; Wentzel, 2017). In contrast to this pandemic, first-year students can only build 


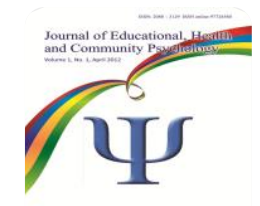

their peer relations online and communicate through social media and other online platforms (Cahya, 2020). Moreover, they are forced to carry out the learning process online with no face-toface meeting during the pandemic, which can provide stress and anxiety that causes a decrease in motivation. Therefore, this study aimed to describe the quality of online-formed peer relationships and the academic motivation of first-year students. Then, we also found out how peer relationships and their factors affect the academic motivation of first-year students, including their achievement (grade point average).

\section{Method}

Design

The approach used in this study is a quantitative non-experimental approach - conducted by collecting numerical data to provide an accurate description of a situation or phenomenon (Christensen, 2007). This study used a correlational research design to determine how strong the peer relationships variable can predict students' academic motivation.

\section{Participants}

The participants in this study were first-year students in a university conducting online learning. The sample was obtained through the probability sampling technique, specifically simple random sampling, where every individual has the same opportunity to be involved in the study. This sampling method was chosen because the researcher had access to the target population, first-year students from one faculty at a university, amounting to 152 people. Thus, through the sample estimate formula by Scheaffer et al. (2012) with bound of error $=0.05$ and proportion $=0.5$, we obtained a sample size of 118 students.

\section{Measurement}

The measuring instrument in this research was in the form of an online questionnaire via Google Form consisting of the Friendship Qualities Scale by Bukowski et al. (1994) and Academic Motivation Scale by (Vallerand et al. (1992). Both of these scales have been used in various studies before, measuring friendship qualities (Doumen et al., 2012; Leung, Wong, \& Farver, 2018; Wood, Bukowski, 
\& Santo, 2017) and academic motivation (Bașal \& Eryılmaz, 2020; Matthews, Hoessler, Jonker, \& Stockley, 2013; Reza, 2015; Smith, Davy, \& Rosenberg, 2012). Friendship Qualities Scale consists of 23 items that were previously translated and adjusted to the online context. The Friendship Qualities Scale adaptation process were carried out according to the International Test Commission (ITC) in Bartram et al. (2018). Two certified English language experts did the FQS forward and backward translation from English to Indonesian. Then, the items were adjusted and reviewed by three educational psychologists who are also experts in English. Based on the Confirmatory Factor Analysis, this instrument meets the model fit criteria by Hair et al. $(2018)$ with $X^{2}(67, N=118)=$ 96.48I, $\mathrm{p}=0.0 \mathrm{I}$ I, RMSEA of $0.06 \mathrm{I}$ (lower than 0.08), CFI of $0.95 \mathrm{I}$ (higher than 0.90), GFI of 0.906 (higher than 0.90), TLI of 0.933 (higher than 0.90), and SRMR of 0.053 (lower than 0.08). In addition, the FQS was also found to be reliable with Cronbach's alpha of 0.907. As for each dimension, namely companionship, help, security, conflict, and closeness have reliability ranging from 0.614 to 0.819 .

In FQS, participants responded on a I to 5 point Likert Scale from strongly disagree to strongly agree. Some of the items in the FQS include: (I) Teman saya dan saya menghabiskan semua waktu luang kami bersama melalui media sosial [My friend and I spend all our free time together through social media], (2) Jika saya memiliki masalah di sekolah atau di rumah, saya dapat menceritakannya kepada teman saya [If I have a problem at school or at home, I can tell my friends], (3) Teman saya membantu saya ketika saya mengalami suatu masalah [My friend helps me when I have a problem], etc. The calculation of the FQS score was done by adding up the scores of each question item. The higher the score obtained by the participant, the higher the quality of the peer relationships. The calculation was also done for dimensions scores.

Then, to measure academic motivation, we used the Academic Motivation Scale (Vallerand et al., 1992), which had previously been translated into Indonesian and adapted by Natalya (2018) for a shorter version. Based on the Confirmatory Factor Analysis, Academic Motivation Scale meets the model fit criteria by Hair et al. (20I8) with $X^{2}(I 7, N=I I 8)=23.852, p=0.124$, RMSEA of 0.069, CFI of 0.973 , GFI of 0.937 , TLI of 0.956 , and SRMR of 0.079 . In addition, the AMS was also found to be reliable with Cronbach's alpha of 0.891 . As for each dimension, namely intrinsic, extrinsic, and amotivation has reliability ranging from 0.752 to 0.853 . The Academic Motivation Scale - Bahasa 


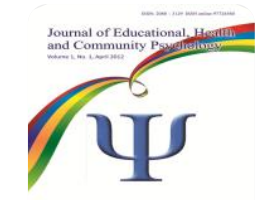

Indonesia Short Version consists of 15 items that responded on a I to 6 point Likert Scale from strongly disagree to agree strongly. Some of the items in the AMS include: (I) Saya merasa kuliah ini berguna untuk karir yang saya inginkan [I find this course useful for the career I want], (2) Saya senang menemukan hal-hal yang belum pernah saya ketahui sebelumnya [I enjoy discovering things I have never known before], (3) Karena perkuliahan ini memberi saya kepuasan personal dari proses untuk menguasai materinya secara mendalam [Because this course gives me personal satisfaction from the process of mastering the material in depth], etc. The calculation of the AMS score was done by adding up the scores of each question item and dimension. The higher the score obtained by the participant, the higher the academic motivation.

Several additional information was collected to provide more comprehensive findings, namely Grade Point Average (GPA) and interaction mode. The participants' interaction modes were collected because, according to Chan \& Cheng (2004), there is a difference in friendships quality between friendships done entirely online (CMC) and face-to-face. Meanwhile, their GPA was collected because, in light of the findings from Li, Peng, Lu, Liao, \& Li (2020) and Smith, Davy, \& Rosenberg (20I2), there was a positive correlation between GPA and students' motivation to achieve good academic performance.

\section{Data Collection}

The data collection process was carried out online via Google Form for first-year students who have been taking online learning for approximately 12 months. First, the research subjects were selected randomly through their student ID numbers. The selected students were then invited to participate in this study. We contacted them to give some information about this research. Through informed consent, participants who agreed to participate in this research were directed to access a link to the questionnaire page asking for their identity, peer relations interaction mode (online or face-to-face), and the measurement instrument (AMS and FQS). Previously, this research procedure obtained ethical clearance from the Research Ethics Commission of Universitas Padjadjaran with 637/UN6.KEP/EC/202I. 


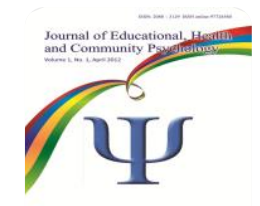

\section{Statistical Analyses}

The statistical analysis was carried out using IBM SPSS Statistics 24 software. Descriptive analysis was performed on two measuring instruments, the Friendship Qualities Scale and the Academic Motivation Scale. Pearson correlation test was then conducted to find the relationships of each dimension in the FQS and AMS scores. A regression test was also conducted to find the role of FQS and its dimensions on academic motivation. Further, a T-test was conducted on FQS and AMS data to determine differences in the quality of peer relationships and academic motivation between participants who had and never met or interacted face-to-face.

\section{Results}

A total of 118 first-year students became participants in this study. The participants consisted of $83.9 \%$ women $(n=99)$ and $16.1 \%$ men $(n=19)$. A total of $52.5 \%(n=62)$ of the participants claimed that they have met and interacted with their college peers face-to-face. Meanwhile, $47.5 \%(n=56)$ of other participants claimed that they have never met face-to-face with their college peers and fully interacted online.

Based on Table I, it can be seen that in the FQS, the participants obtained a mean score of 3.46 $(S D=0.53)$. In this case, the mean score above the middle point shows participants' high peer relationships quality. From the five dimensions in the FQS, it was found that the closeness dimension had the highest mean $(M=3.93, S D=0.64)$, and the lowest was a conflict $(M=2.42, S D=0.70)$. Meanwhile, for the AMS, participants obtained a mean score of $4.45(S D=0.45)$ with the highest mean on extrinsic motivation $(M=4.68, S D=0.68)$ and the lowest on amotivation dimension $(M=1.83$, $S D=0.86)$. The mean score of AMS is above the middle point showing high academic motivation in participants. 


\section{F}

Table I

Descriptive Statistics and Correlations for Peer Relationships and Academic Motivation

\begin{tabular}{|c|c|c|c|c|c|c|c|c|c|c|c|c|}
\hline Variable & $M$ & SD & I & 2 & 3 & 4 & 5 & 6 & 7 & 8 & 9 & 10 \\
\hline I. Companionship & 3.78 & .86 & - & & & & & & & & & \\
\hline 2. Conflict & 2.42 & .70 & $.49 * *$ & - & & & & & & & & \\
\hline 3. Help & 3.74 & .58 & $.63^{* *}$ & $.34 * *$ & - & & & & & & & \\
\hline 4. Security & 3.82 & .61 & $.66 * *$ & $.32 * *$ & $.56 * *$ & - & & & & & & \\
\hline 5. Closeness & 3.93 & .64 & $.75^{* *}$ & $.42 * *$ & $.57 * *$ & $.66^{* *}$ & - & & & & & \\
\hline 6. FQS & 3.46 & .53 & $.89 * *$ & $.66 * *$ & $.77^{* *}$ & $.77 * *$ & $.86 * *$ & - & & & & \\
\hline 7. Intrinsic & 4.68 & .68 & $.36 * *$ & $.20 *$ & $.36 * *$ & $.48 * *$ & $.47 * *$ & $.45^{* *}$ & - & & & \\
\hline 8. Extrinsic & 5.01 & .77 & $.37 * *$ & $.22 *$ & $.32 * *$ & $.44 * *$ & $.40 * *$ & $.42 * *$ & $.6 I^{* *}$ & - & & \\
\hline 9. Amotivation & 1.83 & .86 & $-.22 *$ & .05 & $-.19 *$ & $-.37 * *$ & $-.33 * *$ & $-.23 *$ & $-.5 I * *$ & $-.48 * *$ & - & \\
\hline 10. AMS & 4.45 & .45 & $.40 * *$ & $.28 * *$ & $.37 * *$ & $.48 * *$ & $.46^{* *}$ & $.48 * *$ & $.88 * *$ & $.84 * *$ & $-.34 * *$ & - \\
\hline
\end{tabular}

The correlation test results show that all dimensions in the FQS have a significant correlation with the AMS score. The highest correlation is in the security dimension $(r=0.482, p<0.001)$. Meanwhile, the lowest correlation is in the conflict dimension between $r=0.050(p=0.60 I)$ and $r=0.280$ $(p=0.003)$. It was found that FQS had a significant role in academic motivation with $R^{2}=0.319, F(5$, 10.504), $p<0.001$. This means that peer relationships had a $31.9 \%$ contribution to students' academic motivation. Dimensionally, security $(p=0.002)$ and closeness $(p=0.028)$ had a significant role on academic motivation. However, the correlation test found no significant correlation between participants' academic motivation and grade point average with $r(116)=0.119, p=0.201$. 


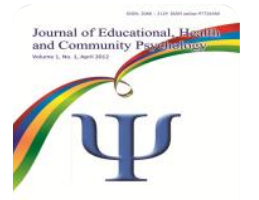

Table 2

Comparison Between Two Participant Groups

\begin{tabular}{|c|c|c|c|c|c|c|}
\hline \multirow{2}{*}{ Variable } & \multicolumn{2}{|c|}{ Online } & \multicolumn{2}{|c|}{ Face-to-Face } & \multirow{2}{*}{$t(1 \mid 6)$} & \multirow{2}{*}{$\mathrm{P}$} \\
\hline & $M$ & SD & $M$ & SD & & \\
\hline Companionship & 3.59 & .97 & 3.98 & .71 & -2.46 & $.01 *$ \\
\hline Conflict & 2.28 & .71 & 2.54 & .66 & -2.02 & $.04 *$ \\
\hline Help & 3.63 & .63 & 3.84 & .51 & -1.97 & .05 \\
\hline Security & 3.76 & .68 & 3.87 & .54 & -0.98 & .33 \\
\hline Closeness & 3.78 & .68 & 4.06 & .57 & -2.41 & $.01 *$ \\
\hline FQS & 3.45 & .61 & 3.69 & .43 & -2.49 & $.01 *$ \\
\hline Intrinsic & 4.57 & .72 & 4.79 & .62 & -1.77 & .08 \\
\hline Extrinsic & 4.96 & .75 & 5.14 & .69 & -1.35 & .18 \\
\hline Amotivation & 1.98 & .89 & 1.69 & .80 & 1.89 & .06 \\
\hline AMS & 4.79 & .64 & 5.00 & .57 & -1.92 & .06 \\
\hline
\end{tabular}

*. Correlation is significant at the 0.05 level (2-tailed).

Further, participants who had interacted face-to-face $(M=3.69, S D=0.43)$ had a higher FQS mean score than those who interacted fully online $(M=3.45, S D=0.6 \mathrm{I})$. However, the two mean scores are still considered high because it is above the middle point. Nevertheless, the results show a significant difference in the participants' FQS scores between the face-to-face and online groups with $\mathrm{t}(\mathrm{I} \mid \mathrm{I})=$ =2.49, $P=0.01$. Participants who had interacted face-to-face $(M=5.00, S D=0.57)$ also had higher academic motivation than those who interacted fully online $(M=4.79, S D=0.64)$. Both of the mean scores are above the middle point. However, there was no significant difference between those mean scores $[t(|| 6)=-1.92, p=0.06]$.

\section{Discussion}

This research attempted to find the role of online-formed peer relationships on students' academic motivation during the online learning period. Based on the study results, it was found that the quality of peer relationships plays a significant role in students' academic motivation. Even in an online context, this finding seemed to be in line with previous studies (Amin et al., 2018; Buote et al., 2007; Willard W Hartup \& Stevens, 1997; Hosan \& Hoglund, 20 I7; Razak \& See, 20 I0; Wentzel \& Watkins, 2002) who found the positive role of peer relationships on individual motivation to learn and obtain 


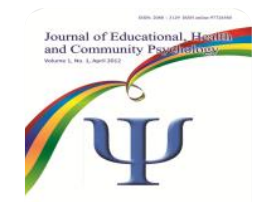

good academic achievement. In this case, peers can be referred to as academic enablers who can facilitate student participation in class (Wentzel \& Watkins, 2002). The facilities provided by these peer relationships consist of giving feedback, achievement parameters (Amin et al., 20l8), and motivation for the students themselves (Razak \& See, 2010). In addition, according to Elliot et al. (2017), the role of peers in motivating students can be explained through two mechanisms, namely informational supports and motivational supports. Through informational supports, peers provide essential information related to learning as tutors and models for their friends.

Meanwhile, on motivational supports, peers provide expressions of attention, rewards, and reinforcement, as well as peer pressure to their friends (Elliot et al., 2017). In an online context, peers could facilitate and assist students' engagement in learning by using social media (Amin et al., 2018). Collaborative online learning involves the active construction of knowledge where students share ideas and information through pair or group communication (Amin et al., 2018). As online discussion occurs, students can learn the subject materials from each other. This strategy provides an advantage for students because they can adapt the learning material to their own needs, have more control over the learning process, and can understand the material more quickly (Cantoni, Cellario, \& Porta, 2004). Therefore, this collaborative learning method has the potential to support online student peer learning to improve academic achievement (Amin et al., 2018).

The role of peer relationships on academic motivation specifically can be explained further by the high correlation between the security dimension and academic motivation compared to other dimensions. Security itself can be defined as the belief that his/her friend is someone who can be relied on and trusted when he/she needs help. Then, security also refers to maintaining friendly relations despite obstacles (Bukowski et al., 1994). In the pandemic, students had to face particular changes in their lifestyle, including quarantine, online learning, forming online relationships, and others. Students had to adapt themselves to the changes, and this could possibly make them face some emotional and behavioral problems, such as anxiety, loneliness, and reductions in peer exchanges (Chen, Cheng, \& Hu, 202I). Moreover, students were found to have high academic stress due to learning pressure, workload, and concerns about grades (Adzkia, 202I). This study shows that participants had relied on their friends when facing those problems. Participants tended to share 


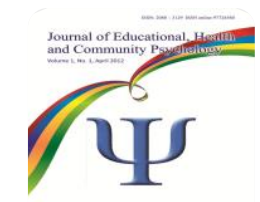

their problems and trust their friends when they needed help. In light of the finding from NabityGrover, Cheung, \& Thatcher (2020), during the pandemic, individuals tend to use social media to find support, entertainment, and connection to others. Hence, participants could also gain support and help from their peers (Mardiawan \& Helmi, 2020) and increase their academic motivation.

Security was also found to have a significant role in academic motivation. That might be related to the research conducted by Wentzel et al. (2004), who found that prosocial behavior, namely cooperation and assistance from friends when facing problems, was related to the process of academic motivation. Wentzel et al. (2004) stated that this correlation could be explained through the presence of prosocial behavior and interactions with friends. These behaviors provide social cues regarding what behavior is appropriate for individuals. In this case, the behavior considered appropriate for a student is studying and getting good grades. In this process, a friend often gives rewards to friends when what is shown matches the coveted personal qualities. Moreover, this reward is also often provided by individuals when their actions increase the stability of their peer relationships (W. W. Hartup, 1983). The existence of assistance and protection within peer relationships is in line with the definition of security by Bukowski et al. (1994), namely reliable alliance dan transcending problems.

In addition, the first-year students also had a high average of closeness. Closeness can be defined as a bond, a feeling of being accepted and validated by a friend (Bukowski et al., 1994). This finding is in line with research by Laursen (1996) and Warren \& Aloia (2018) stated that the frequency of online communication could increase the closeness of a community. In this case, the study participants were college students whose communication was facilitated by the learning process, such as workgroups. The existence of learning activities that are carried out almost every day might increase the frequency of communication between them.

Meanwhile, conflict was found to have the lowest average compared to other dimensions. Moreover, it was the only dimension that had a low mean score below the middle point. This is contrary to research by Ishii (20I0), which stated that computer-mediated communication (CMC) or, in this case, peer relationships in an online context tend to increase conflict. The online situation caused 


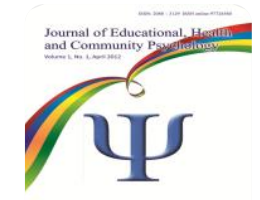

individuals to deal with their conflicts online, which causes difficulties in conflict management. This phenomenon might also be caused by the lack of social-context cues when face-to-face communication is not carried out (Chan \& Cheng, 2004; Ishii, 20I0). However, this study found a low level of conflict between the first-year students. This could be due to differences in the characteristics of participants in these two studies. Research by Ishii (2010) involved participants who are only communicated online. Meanwhile, in this study, some participants had interacted faceto-face. Participants who had interacted face-to-face had a higher mean score of peer relationships (FQS) than those who interacted fully online. This face-to-face relationship might increase socialcontext cues that play a role in avoiding conflict between individuals (Ishii, 20I0).

Given the explanation above, it can be concluded that participants in this study had a high quality of peer relationships due to its score that was higher than the middle point. Moreover, they also had high scores in dimensions that support peer relationships quality, namely companionship, closeness, help, and security. Even in an online context, participants might have a pretty much time spent together on social media or other platforms that caused them to have high companionship. Then, they also might perceive their friends as someone to rely on when faced with problems. In light of findings from Mardiawan \& Helmi (2020), in online context relationships, self-disclosure led students to share their problems with their friends and vice versa. In this way, it can stimulate the mutual help behavior of the sharing partner. If the sharing and helping behavior is appropriately maintained, it can create closeness between them. Thus, this finding might explain how participants scored high in security, closeness, and help. Besides that, conflict was considered one dimension that contributed to the termination of the relationship (Bukowski et al., 1994). Hence, they also had a low score in a conflict which made the quality of their relationships better.

However, even the participants had a high quality of peer relationships, the quality of peer relationships that were carried out entirely online was still lower than face-to-face. This finding is in line with the research by Baiocco et al. (20II), Chan \& Cheng (2004), and Glüer \& Lohaus (2016) that found lower quality of online-formed friendships. Apart from being caused by limited communication channels and lack of social context cues (Chan \& Cheng, 2004), the lower quality of online relationships was also caused by the difficulty of building intimacy (Mesch \& Talmud, 2006; 


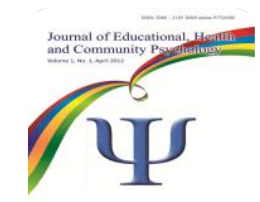

Snow, 2007). Peer relationships can be built with higher reciprocity, emotion, and better interaction through intimacy. Despite that, Chan \& Cheng (2004) stated that CMC can still be comparable to face-to-face relationships given sufficient time and message exchanges. McKenna, Green, \& Gleason (2002) also found that online friendships allow individuals to overcome barriers in offline settings, which made them express themselves more freely without being afraid of getting judged. Therefore, even in this pandemic, participants still managed to form meaningful peer relationships. That might elaborate the correlation findings between peer relationships and academic motivation. Students' academic motivation in this study also became higher through high-quality peer relationships.

Furthermore, previous studies have found that academic motivation is related to student academic achievement (Pekrun et al., 2017; Usher \& Morris, 2012; Vallerand et al., 1992). However, in this study, academic motivation did not seem to significantly correlate with student academic achievement (this study refers to the students' GPA). This finding is in line with previous research by Cetin (20I5) and Schmidt, Zdzinski, \& Ballard (2006), which found a very low correlation between motivation and students' academic achievement. In his research, Cetin (2015) stated that the low variance could cause a low correlation in student GPAs. In addition, various other factors could also play a significant role in individual academic achievement, such as goal setting, students' intelligence, attitude (Cetin, 20I5).

There are several limitations in this study that can later be considered for further research. First, the measuring tool used to measure peer relationships and academic motivation does not specifically measure how friendship or learning process in an online context. In addition, sampling can be done more precisely. The categorization of characteristics between students who have and have never met face-to-face with their peers has not taken into account the frequency or number of times they have met before. Furthermore, this study also only uses samples from a faculty at one university.

\section{Conclusion}

This study found the role of peer relationships on student academic motivation, specifically in online learning. Peers have an essential role as parties who support the student learning process. Even in the pandemic, first-year students seemed to still manage to form meaningful online peer relationships 


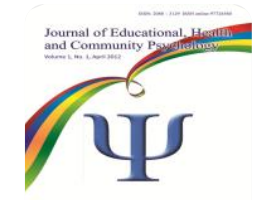

and had a high academic motivation. However, the Covid-19 pandemic that caused learning to be carried out online actually lowered the quality of peer relationships on students who had never interacted with their peers face-to-face. Therefore, students who have never interacted face-to-face with their peers could build a better quality of peer relationships by increasing their communication or to interact face-to-face, especially when the policy of face-to-face learning is implemented, and the pandemic is getting better.

\section{References}

Adzkia, P. D. (202I). Faktor-Faktor yang Berhubungan dengan Tingkat Stres Akademik Siswa SMAN 2 Padang Panjang di Masa Pandemi COVID-19. Universitas Andalas. Retrieved from shorturl.at/tuJK6

Amin, I. M. H., Hassan, N. C., \& Jalil, H. A. (20I8). Predictors of Academic Achievement in Online Peer Learning among Undergraduate Students in a Malaysian Public University. International Journal of Academic Research in Business and Social Sciences, 7(14), 564-587.

Antonopoulou, K., Chaidemenou, A., \& Kouvava, S. (2019). Peer acceptance and friendships among primary school pupils: associations with loneliness, self-esteem, and school engagement. Educational Psychology in Practice, 35(3), 339-35I. Retrieved from https://www.tandfonline.com/doi/full//0.1080/02667363.2019.1604324

Astrini, A. (20II). Masa Orientasi dan Penyesuaian Diri Mahasiswa Baru. Humaniora, 2(I), 452.

Bahasoan, A. N., Wulan Ayuandiani, Muhammad Mukhram, \& Aswar Rahmat. (2020). Effectiveness of Online Learning In Pandemic Covid-19. International Journal of Science, Technology \& Management, I(2), I00-106.

Baiocco, R., Laghi, F., Schneider, B. H., Dalessio, M., Amichai-Hamburger, Y., Coplan, R. J., Koszycki, D., et al. (20II). Daily Patterns of Communication and Contact Between Italian Early Adolescents and Their Friends. Cyberpsychology, Behavior, and Social Networking, 14(7-8), 46747I. Retrieved from http://www.liebertpub.com/doi/I0.1089/cyber.2010.0208

Bartram, D., Berberoglu, G., Grégoire, J., Hambleton, R., Muniz, J., \& van de Vijver, F. (20I8). ITC Guidelines for Translating and Adapting Tests (Second Edition). International Journal of Testing, I8(2), I0I-134. Retrieved from https://www.tandfonline.com/doi/full/10.1080//5305058.2017.1398166

Bașal, A., \& Eryılmaz, A. (2020). Engagement and affection of pre-service teachers in online learning in the context of COVID 19: engagement-based instruction with web 2.0 technologies vs direct transmission instruction. Journal of Education for Teaching, 00(00), I-3. Routledge. Retrieved from https://doi.org/I0.1080/02607476.2020.184I555

Bornstein, M. H., Davidson, L., Keyes, C. L. M., \& Moore, K. A. (2003). Well-being: Positive development across the life course. Well-Being: Positive Development Across the Life Course. New Jersey: Taylor \& Francis. 
Bukowski, W. M., Hoza, B., \& Boivin, M. (1994). Measuring friendship quality during pre-and early adolescence: The development and psychometric properties of the friendship qualities scale. Journal of Social and Personal Relationships, II, 47I-484.

Buote, V. M., Pancer, S. M., Pratt, M. W., Adams, G., Birnie-Lefcovitch, S., Polivy, J., \& Wintre, M. G. (2007). The importance of friends: Friendship and adjustment among Ist-year university students. Journal of Adolescent Research, 22(6), 665-689.

Cahya, G. H. (2020). Generation Zoom: Freshmen forced to start university life in solitude. The Jakarta Post. Retrieved from https:/www.thejakartapost.com/news/2020/09/24/generationzoom-freshmen-forced-to-start-university-life-in-solitude.html

Cantoni, V., Cellario, M., \& Porta, M. (2004). Perspectives and challenges in e-learning: towards natural interaction paradigms. Journal of Visual Languages \& Computing, 15(5), 333-345. Retrieved from https://linkinghub.elsevier.com/retrieve/pii/SI045926X04000I 63

Cetin, B. (20I5). Academic Motivation And Self-Regulated Learning In Predicting Academic Achievement in College. Journal of International Education Research (JIER), II (2), 95-I06.

Chan, D. K. S., \& Cheng, G. H. L. (2004). A comparison of offline and online friendship qualities at different stages of relationship development. Journal of Social and Personal Relationships, 2 I(3), 305-320.

Chen, L., Cheng, R., \& Hu, B. (202I). The Effect of Self-Disclosure on Loneliness in Adolescents During COVID-19: The Mediating Role of Peer Relationships. Frontiers in Psychiatry, 12. Retrieved from https://www.frontiersin.org/articles/ 10.3389/fpsyt.202I.7I05I5/full

Chiu, T. K. F., Lin, T. J., \& Lonka, K. (202I). Motivating Online Learning: The Challenges of COVID19 and Beyond. Asia-Pacific Education Researcher, 30(3), 187-190. Springer Singapore. Retrieved from https://doi.org/10.1007/s40299-021-00566-w

Christensen, L. B. (2007). Experimental methodology (10th ed.). Boston: Pearson. Retrieved from http://books.google.com/books?id=VIItAQAAMAAJ

Deci, E. L., \& Ryan, R. M. (1985). Intrinsic Motivation and Self-Determination in Human Behavior. New York: Plenum Press. Retrieved from https://doi.org/10.1007/978-1-4899-227I-7

Doumen, S., Smits, I., Luyckx, K., Duriez, B., Vanhalst, J., Verschueren, K., \& Goossens, L. (20I2). Identity and perceived peer relationship quality in emerging adulthood: The mediating role of attachment-related emotions. Journal of Adolescence, 35(6), |4I7-|425. Elsevier Ltd. Retrieved from http://dx.doi.org/10.1016/j.adolescence.2012.01.003

Elliot, A. J., Dweck, C. S., \& Yeager, D. S. (2017). Handbook of competence and motivation: Theory and application. Handbook of competence and motivation: Theory and application., 2nd ed. Retrieved from

http://ebookcentral.proquest.com/lib/brunelu/detail.action?doclD=4837497\%0Ahttp://search.e bscohost.com/login.aspx?direct=true \&db=psyh\&AN=2017- $1759 \mid-001$ \&site=ehost-live

Estiane, U. (20I5). Pengaruh dukungan sosial sahabat terhadap penyesuaian sosial mahasiswa baru di lingkungan perguruan tinggi. Jurnal Psikologi Klinis dan Kesehatan Mental, 4(I), 29-40.

Filade, B. A., Bello, A. A., Uwaoma, C. O., Anwanane, B. B., \& Nwangburuka, K. (2019). Peer group 
influence on academic performance of undergraduate students in Babcock University, Ogun State. African Educational Research Journal, 7(2), 8I-87.

Furrer, C., \& Skinner, E. (2003). Sense of relatedness as a factor in children's academic engagement and performance. Journal of Educational Psychology, 95(I), 148-162.

Glüer, M., \& Lohaus, A. (2016). Participation in social network sites: Associations with the quality of offline and online friendships in German preadolescents and adolescents. Cyberpsychology: Journal of Psychosocial Research on Cyberspace, 10(2).

Hair, J. F., Black, W. C., Babin, B. J., Anderson, R. E., Black, W. C., \& Anderson, R. E. (20l8). Multivariate Data Analysis.

Hanesty, E., Neviyarni, \& Karneli, Y. (202I). Factors Affecting Student Learning Motivation During the Covid-I 9 Pandemic. International Journal of Applied Counseling and Social Sciences, 02(0I), I00107.

Hartnett, M. (2016). The Importance of Motivation in Online Learning. Motivation in Online Education (pp. 5-32). Singapore: Springer Singapore. Retrieved from http://link.springer.com/ 10.1007/978981-10-0700-2_2

Hartup, W. W. (1983). Peer relations. Handbook of child psychology (pp. 103-196). New York: Wiley. Hartup, Willard W, \& Stevens, N. (1997). Friendships and adaptation in the life course. Psychological Bulletin, I 2 I (3), 355-370. US: American Psychological Association.

Hosan, N. E., \& Hoglund, W. (2017). Do teacher-child relationship \& friendship quality matter for children's school engagement \& academic skills? School Psychology Review, 46(2), 20I-2I8.

Ishii, K. (2010). Conflict management in online relationships. Cyberpsychology, Behavior, and Social Networking, 13(4), 365-370.

Laursen, B. (1996). Closeness and conflict in adolescent peer relationships. The company they keep: Friendship in childhood and adolescence, (May).

Lee, P. S. N., Leung, L., Lo, V., Xiong, C., Wu, T., Doumen, S., Smits, I., et al. (2020). Influence of adolescents' peer relationships and social media on academic identity. School Psychology Review, 8(2), I-I0. Routledge. Retrieved from http://dx.doi.org/I0.1080/0309877X.20I7.I302568

Leung, A. N. M., Wong, N., \& Farver, J. M. (2018). Cyberbullying in Hong Kong Chinese students: Life satisfaction, and the moderating role of friendship qualities on cyberbullying victimization and perpetration. Personality and Individual Differences, 133, 7-12. Retrieved from https://linkinghub.elsevier.com/retrieve/pii/SOI91886917304592

Li, L., Peng, Z., Lu, L., Liao, H., \& Li, H. (2020). Peer relationships, self-efficacy, academic motivation, and achievement in Zhuang adolescents: A moderated mediation model. Children and Youth Services Review, I/8(June), 105358. Elsevier. Retrieved from https://doi.org/10.1016/j.childyouth.2020.105358

Mardiawan, O., \& Helmi, A. (2020). The Dynamic of Online Friendship Quality: Exploration of Adolescence in Bandung. Proceedings of the Proceedings of the First Brawijaya International Conference on Social and Political Sciences, BSPACE, 26-28 November, 2019, Malang, East Java, Indonesia. EAI. Retrieved from http://eudl.eu/doi/I0.4I08/eai.26-I I-2019.2295200 
Matthews, A., Hoessler, C., Jonker, L., \& Stockley, D. (20/3). Academic Motivation in Calculus. Canadian Journal of Science Mathematics and Technology Education, 13, I-I7.

Maunder, R., \& Monks, C. P. (2019). Friendships in middle childhood: Links to peer and school identification, and general self-worth. British Journal of Developmental Psychology, 37(2), 21I-229. Retrieved from https://onlinelibrary.wiley.com/doi/I0.I I I //bjdp. 12268

McKenna, K. Y. A., Green, A. S., \& Gleason, M. E. J. (2002). Relationship Formation on the Internet: What's the Big Attraction? Journal of Social Issues, 58(I), 9-3I. Retrieved from https://onlinelibrary.wiley.com/doi/I 0. I I I I/I540-4560.00246

Mesch, G. S., \& Talmud, I. (2006). Online Friendship Formation, Communication Channels, and Social Closeness. International Journal of Internet Science, I(I), 29-44.

Nabity-Grover, T., Cheung, C. M. K., \& Thatcher, J. B. (2020). Inside out and outside in: How the COVID-I9 pandemic affects self-disclosure on social media. International Journal of Information $\begin{array}{lllll}\text { Management, } & 55, & 02188 . & \text { Retrieved from }\end{array}$ https://linkinghub.elsevier.com/retrieve/pii/S026840I22031033I

Natalya, L. (2018). Validation of Academic Motivation Scale: Short Indonesian Language Version. ANIMA Indonesian Psychological Journal, 34(I), 43-53.

Paulino, P., Sá, I., \& Silva, A. L. da. (2016). Self- regulation of motivation: Contributing to students' learning in middle school (PP. 1-6). Retrieved from http://www.futureacademy.org.uk/files/images/upload/I -iccsbs_3564_5722_fullText_I_26.pdf

Pekrun, R., Lichtenfeld, S., Marsh, H. W., Murayama, K., \& Goetz, T. (2017). Achievement Emotions and Academic Performance: Longitudinal Models of Reciprocal Effects. Child Development, 88(5), 1653-1670.

Razak, R. A., \& See, Y. C. (2010). Improving academic achievement and motivation through online peer learning. Procedia - Social and Behavioral Sciences, 9, 358-362.

Reza, I. F. (20I5). Hubungan Antara Motivasi Akademik Dengan Prokrastinasi Akademik Pada Mahasiswa. Humanitas, I2(I), 39.

Rohrbeck, C. A., \& Garvin, M. (2003). Peer Relationships: promoting positive peer relationships during adolescence. Encyclopedia of Primary Prevention and Health Promotion, (August).

Samudro, E. G., \& Madjid, M. A. (2020). Pemerintah Indonesia Menghadapi Bencana Nasional Covid - 19 Yang Mengancam Ketahanan Nasional. Jurnal Ketahanan Nasional, 26(2), 132.

Scheaffer, R. L., Mendenhall III, W., Ott, R. L., \& Gerow, K. (20I2). Elementary Survey Sampling. Boston, Massachusetts: Cengage Learning.

Schmidt, C. P., Zdzinski, S. F., \& Ballard, D. L. (2006). Motivation Orientations, Academic Achievement, and Career Goals of Undergraduate Music Education Majors. Journal of Research in Music Education, 54(2), 138-153. Retrieved from http://journals.sagepub.com/doi/I0.I I77/002242940605400205

Schuitema, J., Peetsma, T., \& van der Veen, I. (2016). Longitudinal relations between perceived autonomy and social support from teachers and students' self-regulated learning and achievement. Learning and Individual Differences, 49, 32-45. Retrieved from 
https://linkinghub.elsevier.com/retrieve/pii/SI0416080I6300553

Shanti, T. I., Janssens, J. M. A. M., \& Setiadi, B. (2021). Friends' Support, Motivation to Learn, Emotional Adjustment, and Academic Performance among Indonesian First-year students. Jurnal Psikologi, 48(2), 67. Retrieved from https://jurnal.ugm.ac.id/jpsi/article/view/34060

Smith, K. J., Davy, J. A., \& Rosenberg, D. L. (2012). An empirical analysis of an alternative configuration of the Academic Motivation Scale. Assessment in Education: Principles, Policy and Practice, 19(2), 23I-250.

Snow, E. (2007). Intimacy and Face-to-Face versus Computer Interaction. Undergraduate Review, 3, 37-50. Retrieved from http://vc.bridgew.edu/cgi/viewcontent.cgi?article=1053\&am

Tang, L. (2010). Development of online friendship in different social spaces: A case study. Information Communication and Society, 13(4), 615-633.

Tokuno, K. A. (1986). The early adult transition and friendships: Mechanisms of support. Adolescence.

US: Libra Publishers.

Usher, E. L., \& Morris, D. B. (20I2). Academic Motivation. In N. M. Seel (Ed.), (pp. 36-39). Boston, MA: Springer US. Retrieved from https://doi.org/10.1007/978-I-44I9-I428-6_834

Vallerand, R. J., Pelletier, L. G., Blais, M. R., Briere, N. M., Senecal, C., \& Vallieres, E. F. (1992). The Academic Motivation Scale: A Measure of Intrinsic, Extrinsic, and Amotivation in Education. Educational and Psychological Measurement. Educational and Psychological Measurement.

Warren, R., \& Aloia, L. (2018). Parent-Adolescent Communication Via Mobile Devices: Influences on Relational Closeness. Journal of Family Issues, 39(15), 3778-3803. Retrieved from http://journals.sagepub.com/doi/I0.1 I77/01925 I3X18793924

Wentzel, K. R. (20I7). Peer relationships, motivation, and academic performance at school. The Guilford Press.

Wentzel, K. R., Barry, C. M. N., \& Caldwell, K. A. (2004). Friendships in middle school: Influences on motivation and school adjustment. Journal of Educational Psychology, 96(2), 195-203.

Wentzel, K. R., \& Watkins, D. E. (2002). Peer relationships and collaborative learning as contexts for academic enablers. School Psychology Review, 3I(3), 366-377.

Wilkesmann, U., \& Virgillito, A. (20I5). Academic Motivation of Students - The German Case, (May). Wood, M. A., Bukowski, W. M., \& Santo, J. B. (2017). Friendship security, but not friendship intimacy, moderates the stability of anxiety during preadolescence. Journal of Clinical Child \& Adolescent Psychology, 46(6), 798-809. Taylor \& Francis.

ZA, S., Putra, D. I., Sofyan, S., \& Bimo. (2020). Pedoman Umum Menghadapi Pandemi Covid-I 9 Bagi Pemerintah Daerah. Kementerian Dalam Negeri RI. Retrieved from https://covid I 9.kemkes.go.id/protokol-covid-19/pedoman-umum-menghadapi-pandemi-covid19-bagi-pemerintah-daerah 